\title{
Understanding Mineral Carbonate Formation under Supercritical Conditions using Electron Microscopy and Atom Probe Tomography
}

\author{
B.W. Arey, D.E. Perera, L. Kovarik, R. J. Colby, O. Qafoku, A. R. Felmy \\ Pacific Northwest National Laboratory, Richland, WA 99354
}

Olivines, a significant constituent of basaltic rocks, have the potential to immobilize permanently $\mathrm{CO}_{2}$ after it is injected in the deep subsurface, due to carbonation reactions occurring between $\mathrm{CO}_{2}$ and the host rock. To investigate the reactions of olivine minerals, forsterite $\left(\mathrm{Mg}_{2} \mathrm{SiO}_{4}\right)$ and fayalite $\left(\mathrm{Fe}_{2} \mathrm{SiO}_{4}\right)$, with supercritical $\mathrm{CO}_{2}\left(\mathrm{scCO}_{2}\right)$ and formation of mineral carbonates, experiments were conducted at temperatures of $35{ }^{\circ} \mathrm{C}$ to $80{ }^{\circ} \mathrm{C}, 90 \mathrm{~atm}$ pressure and anoxic conditions for fayalite study. For every temperature, the dissolution of forsterite and fayalite was examined both in the presence of liquid water and $\mathrm{H}_{2} \mathrm{O}$-saturated $\mathrm{scCO}_{2}$. It has been recognized that interactions with near to water-saturated non-aqueous fluids are of prime importance in understanding mineralization reactions since the introduced $\mathrm{CO}_{2}$ is likely to contain water initially or soon after injection and the supercritical $\mathrm{CO}_{2}\left(\mathrm{scCO}_{2}\right)$ is less dense than the aqueous phase which can result in a buoyant $\mathrm{scCO}_{2}$ plume contacting the isolating caprock. The experiments were conducted in a high-pressure batch reactor at reaction time extending up to 85 days. The newly formed products were characterized ex-situ using a comprehensive suite of bulk and surface characterization techniques: X-ray diffraction, Scanning Electron Microscopy coupled with Focused Ion Beam, and High Resolution Transmission Electron Microscopy and Atom Probe Spectroscopy. Furthermore nucleation of $\mathrm{Fe}, \mathrm{Mg}$-carbonates during reaction of orthosilicates with $\mathrm{CO}_{2}$ were studied via in situ TEM using a fluid cell and holder.

[1] This work was supported by the U. S. Department of Energy (DOE), Office of Basic Energy Sciences through a Single Investigator Small Group Research (SISGR) grant at Pacific Northwest National Laboratory (PNNL). This research was performed using EMSL, a national scientific user facility sponsored by the Department of Energy's Office of Biological and Environmental Research located at Pacific Northwest National Laboratory. PNNL is operated for DOE by Battelle Memorial Institute under Contract\# DE-AC05-76RL0-1830. 

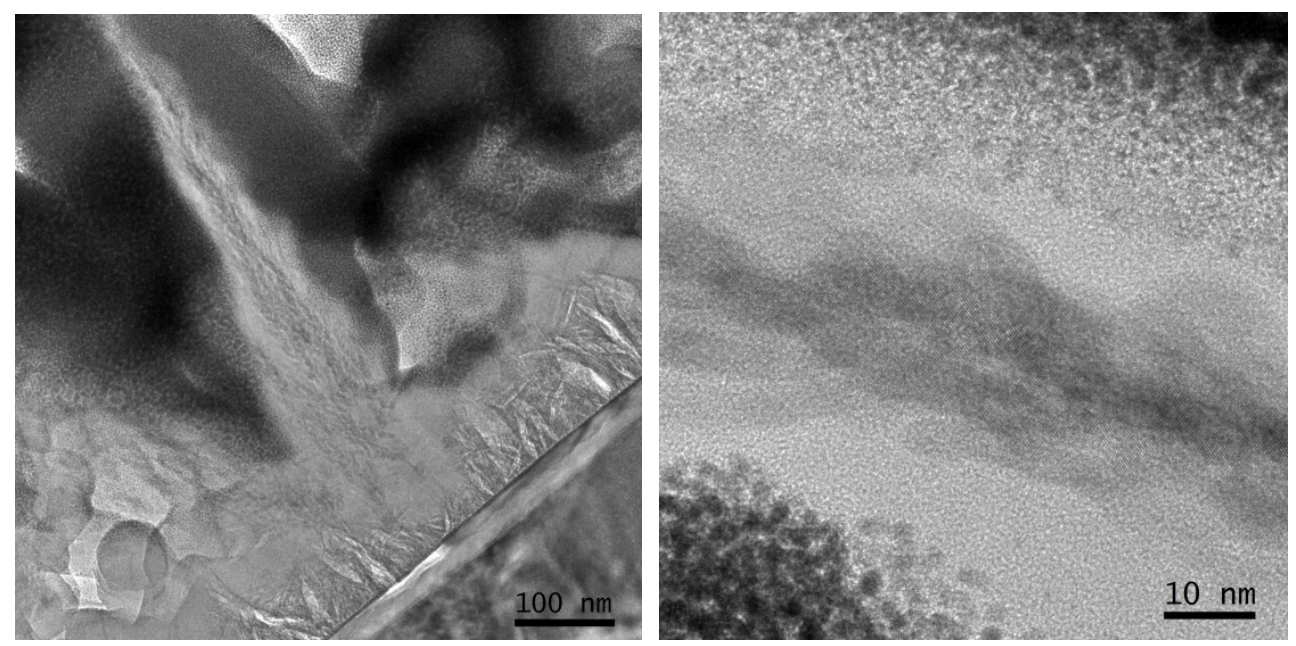

Figure 1. (a) cross section of platelet particles displaying a core identified as hematite; (b) high resolution image of the hematite particle obtained on [441] zone axis.
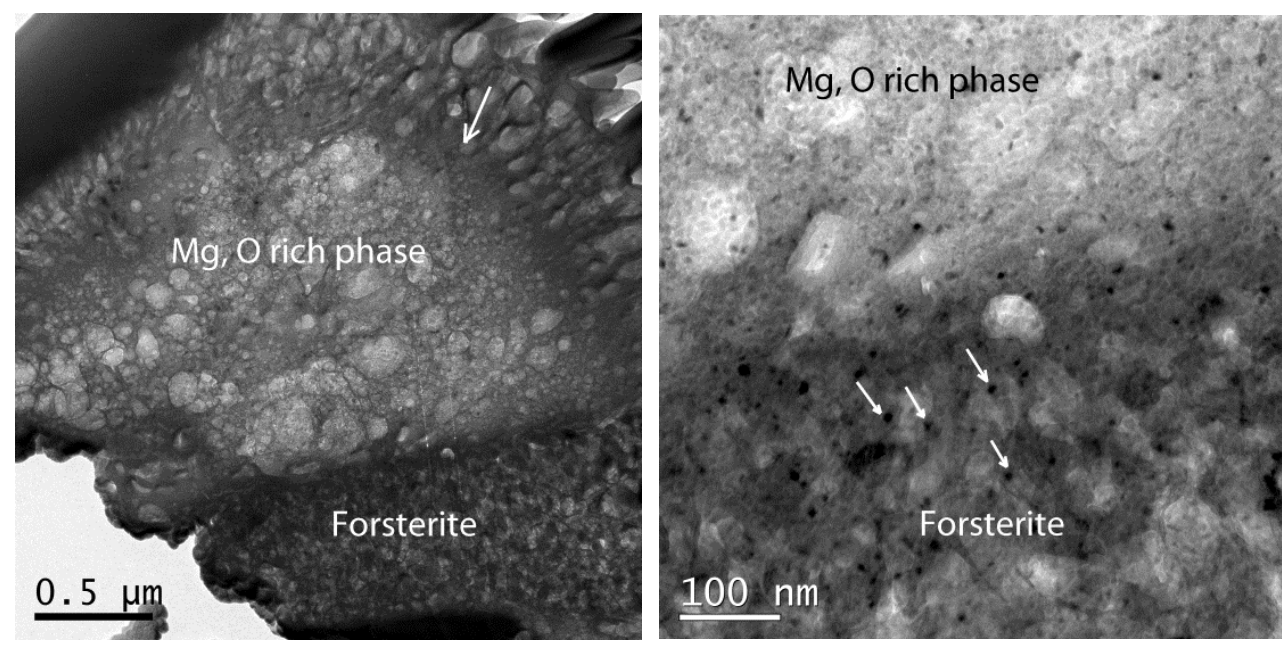

Figure 2. (a) Detail depiction of the interface between the nanocrystalline forsterite and the new precipitate phase. Intergrowth of the new precipitate phase within the forsterite is emphasized with the arrows (b) Atomic resolution view of the new precipitate phase. High density of planar faults was identified in many grains of the new precipitate phase. 